DOI: $10.17516 / 1997-1370-0759$

УДК: 1(091)

\title{
Wonder in the Pedagogy of Antiquity
}

\author{
Sergey I. Bogdanov and Roman V. Svetlov* \\ Herzen State Pedagogical University of Russia \\ St. Petersburg, Russian Federation
}

Received 23.03.2021, received in revised form 06.04.2021, accepted 21.05.2021

\begin{abstract}
The article aims to analyse wonder as a pedagogical phenomenon in ancient philosophy and religion. Aristotle's judgment about mythologists and their interest in the miraculous, which is initially close to philosophy, is reinforced in a rich ancient narrative about amazing people who made amazing discoveries (such as Aristeas from Proconnes, who probably reached Siberia). At the same time, the wonder that the ancient tradition writes about does not have a romantic and aesthetic nature at all, which is often attributed to it. On the contrary, the god Thaumas («Amazing»), mentioned by Plato in «Theaetetus», personifies the numinous phenomena of the sea. Among his descendants is not only the goddess Iris, but also the harpies. Analysis of the texts of Plato and Aristotle shows that the theme of wonder in them is directly related to the themes of blindness, difficulty and even pain that accompany the birth of knowledge. Perhaps the most revealing one is the initiation into philosophy depicted by Plato in «Parmenides», and the myth of cave from the «Republic». The danger from the presence of the gods, which epic theology tells us about, is duplicated by the effort and danger of blindness in the philosophy and rational theology.
\end{abstract}

Keywords: wonder, ancient education, epic and rational theology in antiquity.

The reported study was funded by RFBR according to the research project no. 21-011-44178 (Formation of rational theology in antiquity and the early Middle Ages).

Research areas: theology, history of philosophy.

Citation: Bogdanov, S.I., Svetlov, R.V. (2021). Wonder in the pedagogy of Antiquity. J. Sib. Fed. Univ. Humanit. Soc. Sci., 14(6), 774-781. DOI: 10.17516/1997-1370-0759.

(C) Siberian Federal University. All rights reserved

* Corresponding author E-mail address: spatha@mail.ru

ORCID: 0000-0002-6632-6420 (Bogdanov); 0000-0001-7767-1441 (Svetlov) 


\title{
Удивление в античной педагогике
}

\author{
С.И. Богданов, Р.В. Светлов \\ Российский государственный педагогический \\ университет им. А.И. Гериена \\ Российская Федераиия, Санкт-Петербург
}

\begin{abstract}
Аннотация. Статья имеет своей задачей проанализировать удивление как педагогический феномен в античной философии и религии. Суждения Аристотеля о мифологах и их изначально родственном философии интересу к удивительному получают подкрепление в богатом античном нарративе об удивительных людях, совершивших удивительные открытия (как пример таковых Аристей из Проконнеса, добравшийся, вероятно, до Сибири). Вместе с тем, удивление, о котором пишет античная традиция, вовсе не имеет романтически-эстетической природы, которую ему часто приписывают. Напротив, бог Тавмант («Удивительный»), упоминаемый Платоном в «Теэтете», олицетворяет собой нуминозные явления морской стихии. Среди его потомков не только богиня-вестница Ирида, но и гарпии. Анализ текстов Платона и Аристотеля показывает, что тема удивления в их текстах прямо связана с темами слепоты, трудности и даже боли, которые сопровождают рождение знания. Возможно, наиболее показательным является посвящение в философию, изображенное Платоном в «Пармениде», а также миф о пещере из диалога «Государство». Нуминозная опасность от присутствия богов, о которой нам сообщает эпическая теология, дублируется усилием и опасности слепоты в философии и теологии рациональной.
\end{abstract}

Ключевые слова: удивление, античное образование, эпическая и рациональная теология в античности.

Исследование выполнено при финансовой поддержке РФФИ в рамках научного проекта № 21-011-44178 «Формирование рациональной теологии в античности и раннем средневековье».

Научные специальности: 26.00.00 - теология; 09.00.03 - история философии.

Every teacher seems to understand that wonder is one of the most effective tools to engage students in teaching and learning. Human capacity for wonder is fundamental in homo sapiens. It encourages the development of individuals and human community equally. Wonder provides a student with a new perspective on things and catches their attention. The latter is converted by an experienced teacher into honing new research skills and supporting an interest in research activity in general. The current development of dialogue-based education goes hand in hand with the «pedagogy of wonder» - an original project that should not go unnoticed (Stepichev, 2015).
Whoever focuses on wonder as a teaching tool inevitably recalls that the history of wonder as an educational technique goes back to Ancient Greece. Greeks used it, quite consciously, to encourage students' strive for knowledge. At those days wonder was a philosophical entity; the philosophical paideia, however, embraced both discipline-based teaching and moral and values education. Later, in the Middle Ages, the set of disciplines taught in ancient schools would become the foundation of trivium and quadrivium. Thus, wonder is a driver of learning. The paper aims to assess the accuracy of our modern understanding of wonder's ancient concept. It also aims to identify 
possible chronological inconsistency between more recent models and values attached to it and the original concept.

We will not delve into Plato's or Aristotle's philosophy of education right at the outset. Instead, we will turn to an earlier stage of antiquity - the times when each story about a person who gained new knowledge was underpinned by an attempt to cause wonder. One of such persons was Aristeas of Proconnes, who was said to have a wonderous life. For example, Aristeas was reported to have been at the boundary of the oecumene. Presumably, he had travelled much farther than Greek explorers or even their informants. Aristeas's poem Arimaspea mentions the Issedones and the Arimaspi tribes. The latter try to battle the gold-guarding griffins. The characters of the poem bear a resemblance to the inhabitants of the Trans-Urals and South Siberia. It is highly likely the story about one-eyed giants fighting the monsters for gold is rooted in the myths of Innermost Asia and Siberia. Suffice it to recall the Chinese dragons as guards of wisdom and treasure. This theme was partly borrowed by European mythology with a horrible sleeping dragon who guards gold. Besides, we have ground to believe that Arimaspea was written under the influence of East Asian culture (the Eastern Zhou period). It also bears evidence about the migration of nomadic tribes from the east of Eurasia westwards (Ratcliffe, 2014).

The plot of Aristeas's poem is a combination of real and wondrous. This may be the reason why Aristeas was later credited to have supernatural powers. It was wondrous how he, «possessed by Phoebus», had travelled to the end of the world, resurrected twice and even followed Apollo as a crow (Hrdt. IV.13). The unbelievable facts seem to be corroborated by the unbelievable powers of those who share these facts.

This topos is typical for mythological and early philosophical thinking. For example, a Hyperborean prophet and healer Abaris had supernatural abilities. He was said to have travelled the world with an arrow, fasting all the while - hence his nickname, Abaris the

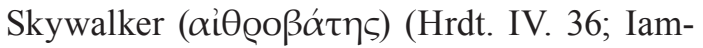

bl. De vita pythag. 136) ${ }^{1}$. Another example is Hermodorus of Clazomenae (in some sources Hermotimus). His soul left the body, went on long journeys around the world and learned a lot new about places remote from Ellada. (Plut. De genio Socr. 592c-d). No less known are the miracles of Pythagoras, whose soul remembered all the bodies it had tenanted, i. e., all the previous lives. Plato, who defined humans as dual, also exploited the topic of the soul going forth from the body in his tale of Er, the son of Armenius (Pl. Rp. 614b-621b).

Shamanistic or supernatural powers often become the focus of research in the irrational component of ancient culture. In his book The Greeks and the Irrational E.R. Dodds says that out-of-body journeys gave ancient Greeks an understanding of soul as a special entity (Dodds, 1951: 135-178). We will take a look at similar shamanistic tales from a different perspective, i. e., the well-established concept of wonder as a source of philosophy supported by Plato and Aristotle. Unlike them, Democritus believed that $\varepsilon \dot{v} \theta v \mu i \alpha$ (serenity) was the major philosophical aspect of soul.

At this point, as an evidence in support of our position, it is reasonable to quote Aristotle's Metaphysics, Book 1, where he claims that the myth-lover is in a sense a philosopher, since myths are composed of wonders (Ar. Met. 982b 18-19). Obviously, Aristotle distinguishes between the mythological approach to describing reality (epic theology) and philosophical discourse (rational theology): men astonish in the first place at obvious perplexities, and then at gradual progression, and raise questions about the greater matters too (Ibid. 12-16). Those who wonder and feel perplexed understand that they are ignorant, therefore, to escape ignorance, they study philosophy. Philosophy does not rely on tales or myths as they cannot be proved. Philosophy relies on evidence and facts. Hence, it is not worthwhile to consider seriously the subtleties of mythologists (Ibid. 1000a 18-19).

Aristotle's «academic purism» quite a while ago became a locus communis of the European history of philosophy, which attempts

\footnotetext{
Interestingly, the Oxyrhynchus Papyrus No. 1611 mentions Abaris alongside the Issedones.
} 
to establish the founder of the Lyceum as the forerunner of empiricism and rationalism of the Modernity. However, a close analysis of the surviving texts and evidence shows that, to begin with, we should be more careful about our judgements.

To some extent, Aristotle regards mythlovers as those on the right track to philosophy. A few decades earlier, Plato in «Theaetetus» showed the link between wonder and establishing oneself as a philosopher:

\section{Theaetetus}

By the gods, Socrates, I am lost in wonder when I think of all these things, and sometimes when I regard them it really makes my head swim.

\section{Socrates}

Theodorus seems to be a pretty good guesser about your nature. For this feeling of wonder shows that you are a philosopher, since wonder is the only beginning of philosophy, and he who said that Iris was the child of Thaumas made a good genealogy (Pl. Thaet. 155c-d, transl. Harold N. Fowler).

Once we look at an object from different perspectives and in different settings, things that seemed clear and obvious transform into something odd and implausible. In our case it is irrelevant that Socrates makes Theaetetus wonder through his criticism of Protagoras's teaching. What is relevant is his reference to Thaumas, son of Pontus and Gaia, a sea god, is associated in the ancient mythological thinking with a range of astounding marine phenomena.

It is known that early Greeks were no lovers of the sea. It was a source of danger with pirates from overseas lands and elemental powers of sea waters. Early Greeks established their colonies along and due to the sea, still, they kept praying gods for benevolence. They mostly addressed their prayers to the Apollo of Delphi and the gods who protected seafarers: the quick-footed Achilles, Leucothea, Palaemon and others. The fear that the early Greeks had of the unpredictable sea is best illustrated in the Odyssey. This means that Thaumas was not associated with intellectual puzzles or miracles, rather, he was associated with the dangerous power of the sea. Socrates makes a reference to his daughter, Iris, and claims that she was a messenger of gods. However, Thaumas and Electra were also parents of the Harpy sisters: Aello (storm swift) and Okypete (swift wind). The two sisters originally personified a sea storm that took away the lives of vessels and sailors (Hesiod. Theog. 265-267).

Plato's understanding of wonder is related to elemental forces of nature. By way of a reminder, the gods of the Greek world were not the ones who created it. They appeared together with the new world and would disappear if the Cosmos came to an end. Some powers are beyond their might and knowledge. This is the power of fate personified in Hesiod's Theogony

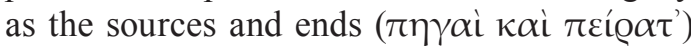
of gloomy earth and misty Tartarus, which even the gods are terrified (Hesiod. Theog. 738-745). The development of Greek philosophy was a bold attempt to gain insights into these sources and ends. Presumably, they are referred to in the only surviving fragment of Anaximander's writing, «Whence things have their origin, thence also their destruction happens» (Simpl. On Aristotle's Physics 24, 13).

Consequently, wonder as a source of myths and philosophy is rooted in the numinous forces of nature that astonish the archaic man. The philosophical domain of wonder demythifies the worldview (Wilson, 2017). Aristotle's observation that things are no longer wondrous once they have been subjected to scrutiny is not accidental. He tells us, «But we must end with the contrary and (according to the proverb) the better view, as men do even in these cases when they understand them; for a geometrician would wonder at nothing so much as if the diagonal were to become measurable» (Ar. Met. 983a 18-21).

On the other hand, Aristotle is unlikely to believe that the resource of wonder is finite. Anyway, it is part of the philosophical path towards the comprehensible. He writes in the «Nicomachean Ethics» about men with a great soul. Obviously, he considered himself to be the one too. Such man is not prone to admiration, since nothing is great to him. (Ar. Nic. 
Eth. 1125a4). No doubt, this only concerns some external circumstances or events as the major field for the wonderous is the intellectual activity which brings the man closer to the God.

Socrates, as depicted by Plato, does not seem to bear any resemblance to the Aristotle's men with a great soul. He focuses on the philosophical essence of wonder in several key writings. The first one is Parmenides that unfolds with Socrates talking to the great Eleatic philosopher. Young Socrates provides arguments against Zeno's paradox about plurality. He claims he would be amazed if someone showed that absolute unity is absolute many and the absolute many is absolute one. Despite the young age, Socrates is experienced enough to see that sophists confuse genus and species. But still, may ideas transform into the opposite?

Parmenides joins the dialogue and promises to amaze Socrates. Early in the dialogue we find quite many words derived from $\theta \alpha \tilde{v} \mu \alpha$ (wonder). Parmenides criticizes Socrates' distinction between abstract ideas and things. In what follows we find the dialectic of one and many and an indication that the principles are consistent. Parmenides says, "Only a man of very great natural gifts will be able to understand that everything has a class and absolute essence» (Pl. Parm. 135a). This dialectic is used as an educational tool. The rest of the dialogue is a rite of passage into the domain of philosophy.

Interestingly, in Plato's «Theaetetus», Socrates recollects his encounter with the Eleatics that took place 50 years before (the dramatic date of the «Theaetetus» is the spring of 399 $\mathrm{BC})$. Socrates says, «Parmenides seems to me to be, in Homer's words, 'one to be venerated' and also 'awful'. For I met him when I was very young and he was very old, and he appeared to me to possess an absolutely noble depth of mind» (Pl. Thaet. 183e. Transl. Harold N. Fowler). Veneration and awe are almost numinous terms indicating an encounter with something holy (if we stick to Rudolf Otto's concepts). In the «Theaetetus», Socrates makes a shrewd reference to the speeches made by Parmenides, which were subject to very complex interpretation routine. This allows him to get back to «Theaetetus» 2 and disburden him from his vision on knowledge. We hear an amusing tone when Socrates is talking about the founder of the Eleatics, yet, we cannot but recall the origin and nature of Thaumas who is represented in the «Theaetetus», through Socrates' effort, as a god of wonder and someone related to philosophy.

Wonder, which led Socrates to become a philosopher (during the events described in the Parmenides), reveals itself in his dialogue with Theaetetus. The young man complains that he does not see at all. Does not it resemble the situation the eighteen-year-old Socrates found himself in once his dualistic theory was debunked? For when the teaching of ideas is wrong, to what can you turn, if these things are unknown? (Pl. Parm. 135c).

Plato often refers to wonder as a driver of thinking. A telling example is «Sophist». Stranger and Theaetetus are trying to understand the nature of sophistry which, at a certain point, escapes their scrutiny through the statement that falsity is non-existent. Once the Stranger understands he has lost the track, he

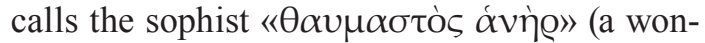
derful fellow) (Pl. Soph. 236d). The wording is intentionally ambiguous since both conjurers and liars may cause wonder. Socrates actually held to the position that the sophist belongs to the class of conjurers. The sleight of the tricky sophist is the source of wonder that encourages the emergence of a philosopher. Apart from wonder, the dialogue also mentions blindness. Both the sophist and the philosopher are hard to discern - the former on the account of darkness, the latter on the account of the brilliant light of the place (Pl. Soph. 254a).

In the «Symposium», Socrates, to some extent, presents philosophy as the power of wonder. At the beginning of his part, Eryximachus calls the god of love wonderful. At the same time, Alcibiades, who arrives at the symposium drunk, says the same about Socrates calling him a truly spiritual and mirac-

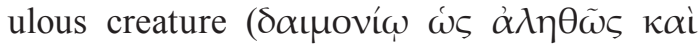
$\theta \alpha v \mu \alpha \sigma \tau \tilde{\omega})$ (Pl. Symp. 219c). However, we remember that beauty does not lie on the surface. It is housed inside as a treasure hidden within a seemingly ugly toy. The only way to approach 
it is to tolerate the pain caused by philosophic discourses (Ibid. 217e-218b).

Sometimes the theme of wonder takes on a joking character in Plato. But even in this case, the humorous text implies a very serious subtext, forcing the reader and the researcher to place even obvious jokes in the context of philosophical discourse. The most impressive example of this might be «Cratylus».

Talking about blindness, one of Plato's writings accurately describes blindness as a condition we inevitably face at different stages of learning and cognition. This is the Allegory of the Cave from Book VII of the «Republic». Initial blindness, when the prisoners do not see the causes of shadows cast on the cave walls and themselves, is replaced by another type of blindness. This is when they look up toward the light to see the real objects. The next stage of blindness is when someone drags them out into the light of genuine and divine sun. The final stage of blindness is the return to the cave still shrouded in darkness. Stage two and three are likely to have a direct reference to wonder that instils a desire to study philosophy. The fourth stage, apparently, draws a dividing line between a philosopher and a layman.

Wonder represented in the sensory image of blindness is a condition when we fail to discern something that used to be obvious. It has nothing to do with a special ancient form of aesthetic admiration for the universe. This is how romanticism treated Greek culture and philosophy. On the contrary, an aporia experienced by conciseness makes us fall into awe. Awe is depicted as blindness that we may overcome only through special effort.

Ancient myths about oracle centres are a prove that effort was instrumental in obtaining knowledge. The most well-known, perhaps, is the tale of the Cave of Trophonius in Lebadeia. Entering the cave was an extremity and those who returned from the fortune-telling journey were paralyzed with terror and unconscious both of themselves and their surroundings. In the cave they answered some questions and then were taken to the temple where they lodged before Good Fortune and Good Spirit in what we would now call «relaxation» (Paus. Perieg. IX. 39). Whatever was happen- ing during the fortune-telling, these processes indicate that learning the future and obtaining new knowledge was accompanied by something numinous.

The above indicates the following: wonder that inspires philosophy has to be seen as a challenge, as an encounter with the unusual, a certain rite of passage. The one who overcomes the challenge will gain new above-the-average skills. Even Plato describes Socrates either as a prophet who discusses the nature of Eros («Phaedrus») or the post-mortem life of souls («Phaedo», «Republic»), as a medium explaining the concept of «giving birth in beauty» («Symposium») or as a wizard whose speeches may compare with a snake bite. Hence, the wondrous journey ascribed to Aristeas as well as his image as Apollo's travel companion are in line with rites of passage into philosophy described by Plato as well as the image of Socrates as Plato's teacher.

As we can see, Aristotle tends to demythify consciousness and de-dramatize the rite of becoming a philosopher. In Metaphysics, Book III, Aristotle provides a list of aporias, i. e., well-defined hindrances or challenges caused by the progression of our thoughts. This list is preceded by the discussion on the ease and difficulty of studying, "Truth is like the proverbial door which no one can miss, in this sense our study will be easy; but the fact that we cannot, although having some grasp of the whole, grasp a particular part, shows its difficulty». What follows is an important metaphor. What if the problem is us, not the nature, «Just as it is with bats' eyes in respect of daylight, so it is with our mental intelligence in respect of those things which are by nature most obvious» (Ar. Met. 993b 10-11, transl. H. Tredennick). Bats, the inhabitants of caves, are quite often referred to in ancient literature. The image of bats may have an internal connection with the mysterious fragment of Aristotle's work (probably, «On Philosophy»), that Cicero quotes in his philosophical dialogue The Nature of the Gods. Aristotle remarks that people who do not know that the gods actually exist but have learned of their existence by hearsay resemble cavemen who have never seen the Sun and the circular motion of celestial bodies. If they came 
forth into the upper world and beheld its beauty, they would assuredly believe both that the gods existed and that these mighty works proceeded from them (Cic. De nat. deor. XXXVII, 95) 2

Unlike the cavemen, bats cannot tolerate sunlight. Similarly, our mind can only see the obvious (finally, Zeno of Elea demanded to prove that motion was not an illusion). We may only understand something obvious by nature yet unclear to us through some extraordinary event, e. g., a collapse of the walls in the cave inhabited by the cavemen. Hence, we cannot do without continuous cognitive training, especially, when it comes to the most challenging issues. For example, the issue of cognizing infinite sets of objects. In Metaphysics, Books II and III, Aristotle makes frequent use of such

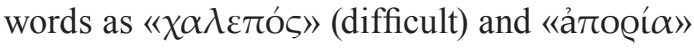
(hindrance), which indicate the key role of intellectual training and difficulty of attaining the results ${ }^{3}$.

Astonishment at the difficulty of the challenge may not only engage a person in studying, it may also paralyze them and cause irritation. The classic example here would be Meno from the namesake dialogue written by Plato who says, "You yourself come in difficulty and other drives in a quandary». Meno considers that Socrates should not voyage or take a trip away from home, «For if you went on like this as a stranger in any other city you would very likely be taken up for a wizard» (P1. Meno. 80a-b). Plato's dialogues effectively demonstrate that the irritation caused by the philosophical meticulousness of Socrates resulted in the charges brought against him. This fact is yet another proof that wonder as part of ancient higher education had nothing to do with an aesthetic context. Quite the op-

\footnotetext{
2 For the discussion of this fragment see paper of Irina Makarova (Makarova, 2017).

3 Ancient scepticism is one of the reactions to paradoxes that arise during philosophical investigations.
}

posite, as it did in the case of Aristeas, «extracting» the knowledge is a challenge that often requires supernatural skills. Moreover, becoming a student of philosophy through wonder is a risky endeavour.

To conclude, we would like to highlight the existence of evidence that even such exceptionally learned men as Aristotle were curious of what we now call the supernatural. Undoubtedly, the Antiquity, unlike the contemporary world, enjoyed the privilege of almost lacking censorship of research avenues. This is the reason why the supernatural, i. e., something beyond the scope of modern science and research, caused wonder and, therefore, necessitated analysis. If we refer to Proclus' commentary on «Republic» by Plato, we find an account of the Hellenistic Peripatetic Clearchus of Soli. He speaks about a magician who persuaded Aristotle that the soul could leave the body. The magician struck a sleeping lad with a soul-

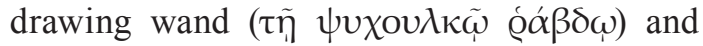
drew out his soul. The boy was motionless as if he were dead. Then, the wand brought the soul back in association with the body and the boy revived (Proclus, in Remp. II. 122.22-123.8) ${ }^{4}$. As anecdotic as it may seem, this fragment is a proof that Aristotle and the members of his school were very careful about what seemed inexplicable. They did not lose focus even if the case presented an argument against the holistic concept of a man described in De Anima, a major treatise written by Aristotle. Wonder had an epistemic and educational potential even when there was a clear dividing line between philosophy and such domains as myths or folk theology, when rational theology with its division of acquiring knowledge of the gods by nature and by learning began its active development (Svetlov, 2019: 10-16).

\footnotetext{
4 This is a fairly debated subject in modern science (Huby, 1979; Dorandi, 2006; Tantlevskiy, 2019: 199-200).
}

\section{References}

Dodds, E.R. (1951). The Greeks and the Irrational. Berkley and Los-Angeles.

Dorandi, T. (2006). Le traité Sur le sommeil de Cléarque de Soles: catalepsie et immortalité de l'âme. In Exemplaria Classica X, 31-52.

Huby, P.M. (1979). The Paranormal in the Works of Aristotle and his Circle. In Apeiron XIII, 52-57.

$$
-780-
$$


Kurdybailo, D.S. (2015). Ot igry k misterii: ob interpretatsii etimologii v dialoge Platona «Kratil» [From game to mystery: on interpretation of etymologies in Plato's Cratylus]. In Plato Investigations, 3 (2), 92-116.

Makarova, I. (2017). Aristotle's Myth of the Cave. In Plato investigations, 7 (2), 27-146.

Ratcliffe, J. (2014). Arimaspians and Cyclopes. In Sino-Platonic Papers, 249 (June 2014), 74 p.

Stepichev, P. (2015). Surprise pedagogy: a new educational paradigm of the XXI century. In Paradigmata poznani, 4, 35-38.

Svetlov, R.V. (2019). Ratsional'naia teologiia v antichnosti [Rational theology in antiquity]. In Proceedings of the Department of Theology of St. Petersburg Theological Academy, 1 (3), 7-16.

Tantlevskiy, I. (2019). Aristotle's Teaching on the Rational Part of Soul in the Context of Plato's «Soteriology». In Plato Investigations, 11 (2), 187-217.

Wilson, J. (2017). Wonder and the discovery of being: Homeric myth and the natural genera of early Greek philosophy. In The Review of Metaphysics, 70 (3), 411-433. 